\title{
PERUBAHAN PERILAKU GROOMING DAN IMOBILITAS MENCIT BALB/C TERINDUKSI DEPRESI YANG DISUPLEMENTASI TEMPE SEBAGAI SUMBER PARAPROBIOTIK
}

Alteration of Grooming and Immobility Behaviour in Depression-Induced Balb/c Mice Supplemented with Tempeh as Paraprobiotic Source

\author{
Vanessa Ardianty ${ }^{1) *}$, Brian Saputra Manurung ${ }^{1)}$ \\ ${ }^{1)}$ Program Studi Biologi, Fakultas Ilmu Hayati, Universitas Surya \\ Jalan MH. Thamrin Tangerang, 15143 \\ *Korespondensi Penulis: vanessa.ardianty@gmail.com
}

\begin{abstract}
Depression, a mental disorder marked by sadness, anhedonia and increased fatigability, is becoming more common in this industry 4.0 era. Nowadays, depression affects approximately 322 million people around the world (more than 14 million in Indonesia) and gives major contribution to the rise of global burden of disease. Although antidepressant is considered the common treatment for depression, recent studies show a possibility to treat depression by altering gut microbiome of the patient, by giving them probiotic food. Tempeh is a globally well-known Indonesian paraprobiotic food which already proven to modulate gut microbiota. This research aimed to find out the effect of tempeh to depression symptom as expressed in Balb/c mice behaviors. The methods used was to feed tempeh or tempeh starter to mice which were depressed-induced by Unpredictable Chronic Mild Stress (UCMS) procedure. Parameter measured were depression level of the Balb/c mice based on immobility times and grooming durations acquired from tail suspension test, forced swim test, sucrose splash test and coat state score. The result showed that tempeh supplementation did not affect coat states and grooming durations but tend to improve immobility times of the Balb/c mice. Meanwhile, tempeh starter supplementation tends to improve the immobility time and kept coat state clean/tidy, but lowered grooming duration. In conclusion, supplementation of paraprobiotic tempeh, especially in starter form, tend to improve depression symptoms.
\end{abstract}

Keywords: depression, mice, paraprobiotic, tempeh

\section{PENDAHULUAN}

Depresi didefinisikan sebagai gangguan mental dengan gejala kemurungan, anhedonia atau kehilangan minat terhadap kesenangan, penurunan energi, perasaan rendah diri, gangguan makan dan tidur, serta penurunan kemampuan berkonsentrasi. Dengan jumlah penderita mencapai \pm 350 juta orang di seluruh dunia, depresi memiliki peran besar terhadap beban kesehatan global. Depresi tidak hanya menurunkan produktivitas kerja dan kualitas hidup penderitanya, tetapi juga, pada kasus yang parah, berpotensi menyebabkan kematian. Tercatat lebih dari 800 ribu jiwa hilang setiap tahunnya akibat bunuh diri, dengan depresi sebagai salah satu pemicunya (World Health Organization, 2015).

Di Indonesia, jumlah persis penderita depresi belum pernah didata secara terperinci. Namun, berdasarkan Riskesdas 2018 yang dilakukan oleh Balitbangkes dengan teknik Mini International Neuropsychiatric Interview (MINI), diketahui penduduk Indonesia yang menderita depresi diperkirakan mencapai $6,1 \%$ dari total penduduk usia $\geq 15$ tahun atau sekitar 14 juta orang. Sebanyak $91 \%$ dari penderita depresi tersebut belum mendapatkan bantuan medis maupun mengonsumsi anti-depresan (Badan Penelitian dan Pengembangan Kesehatan, 2019). 
Secara patofisiologi, depresi tidak memiliki konsep yang utuh, mengingat gejala yang ditunjukkan bervariasi dari penderita satu ke penderita lain, walaupun usaha untuk menjelaskan mekanisme depresi secara neural dan molekular telah dicoba. Gejala fisik/psikologis yang ditunjukkan penderita depresi umumnya berhubungan dengan penurunan jumlah neurotransmiter, perubahan pada kinerja sumbu Hipothalamus-Pituitari-Adrenal (HPA), gangguan pada siklus sirkadian, perubahan pada sistem GABAnergik dan atau serotonergik, dan peralihan pada mekanisme neurotrophic signaling (Krishnan and Nestler, 2008; Hasler, 2010).

Sesuai dengan konsep dari patofisologi depresi dan mekanisme yang mendasarinya, penangganan depresi pada umumnya melibatkan penggunaan obatobatan, seperti antidepresan berbasis monoamine dan psikoterapi, seperti cognitive behavioral therapies/CBT (DeRubeis et al., 2008). Akan tetapi, meskipun metode penanganan yang efektif sudah diketahui, separuh dari penderita depresi masih belum menerima penanganan medis (World Health Organization, 2017).

Di sisi lain, penelitian terbaru menunjukkan penyebab terjadinya depresi tidak hanya berkaitan dengan ketidakseimbangan neurotransmitter, tetapi juga berhubungan dengan komposisi mikrobiota usus. Komposisi mikrobiota usus yang sehat diketahui dapat mendorong kesehatan sistem saraf pusat dan sebaliknya gangguan pada sistem saraf pusat dapat mengganggu keseimbangan mikrobiota usus dan kesehatan pencernaan. Hubungan timbal balik antara otak dan usus ini dikenal dengan istilah Sumbu Otak-Usus (Gut Brain Axis/GBA) (Clapp et al., 2017). Paradigma baru ini menimbulkan ketertarikkan dalam penanganan depresi menggunakan asupan makanan sehat, terutama makanan fermentasi/probiotik (Selhub et al., 2014; Dash et al., 2015).

Berbagai penelitian yang membuktikan efektivitas probiotik dalam mengatasi gejala depresi telah dilakukan. Penelitian oleh Bravo et al. (2011) menunjukkan bahwa pemberian lactic acid bacteria (LAB) mempengaruhi ekspresi reseptor GABA (Gamma aminobutyric acid) di sistem saraf pusat, produksi dari kortikosteron, dan perilaku khas depresi/ kecemasan via saraf vagus. Penelitian lainnya oleh Desbonnet et al. (2010) mengenai pemberian minuman probiotik dengan kandungan Bifidobacterium infantis pada mencit yang diinduksi depresi menunjukkan bahwa pemberian probiotik memulihkan gejala depresi, yang meliputi peningkatan produksi IL-6, penurunan noradrenaline, dan imobilitas atau perilaku pasif pada saat tes renang paksa. Selhub et al. (2014) juga mengulas penggunaan probiotik sebagai alternatif yang menjanjikan untuk penanganan depresi karena kemampuannya mengubah interaksi otak-usus.

Sementara itu, Indonesia memiliki makanan tradisional yang kaya akan probiotik, yakni tempe (Astuti et al., 2000). Tempe merupakan makanan fermentasi dari kedelai yang direkatkan oleh hifa Rhizopus oligosporus, mikroba utama yang biasanya digunakan dalam fermentasi tempe. Akan tetapi, sebenarnya tempe merupakan hasil fermentasi dari campuran berbagai kapang, khamir, LAB, dan bakteri gram negatif, yang menjadikan tempe sangat kaya akan probiotik (Babu et al., 2009).

Berbeda dengan makanan probiotik lain seperti yoghurt dan tape, tempe biasanya tidak dikonsumsi dalam kondisi mentah. Kebiasaan mengonsumsi tempe yang sudah dimasak membuat tempe kurang dianggap sebagai sumber probiotik yang efektif (Nuraida, 2015). Padahal, manfaat tempe tampak tidak berubah meskipun tempe telah diproses, baik dengan direbus maupun digoreng 
(Kuligowski et al., 2013; Soka et al., 2014; Soka et al., 2015). Tempe yang masih memiliki manfaat makanan probiotik setelah dimasak ini disebut paraprobiotik atau probiotik bayangan.

Tempe dalam bentuk paraprobiotik masih dapat memodulasi mikrobiota usus dengan mendorong pertumbuhan bakteri baik dan pembentukan komposisi mikroflora usus yang seimbang/sehat (Soka et al., 2014). Konsumsi tempe yang telah dimasak juga diketahui dapat meningkatkan jumlah Lactobacillus dan Bifidobacterium dalam usus (Kuligowski et al., 2013). Seperti disebutkan sebelumnya, kedua bakteri tersebut merupakan probiotik yang telah diuji sebagai alternatif penanganan depresi (Selhub et al., 2014). Akan tetapi, penelitian tentang efek tempe terhadap gejala depresi belum pernah dilakukan. Oleh karena itu, dengan mempertimbangkan tempe sebagai sumber paraprobiotik yang potensial dalam menangani depresi, penelitian ini akan menganalisis efek tempe terhadap gejala depresi mengunakan model mencit.

Pemodelan depresi dan tes depresi dengan mencit sendiri sudah sering dilakukan (Bergner et al., 2010). Salah satu pemodelan yang cukup sering dilakukan dan terpercaya adalah pemodelan Unpredictable Chronic Mild Stress (UCMS), yaitu induksi depresi dengan pemberian berbagai stressor secara acak dalam jangka waktu tertentu (Nollet et al., 2013). Setelah induksi depresi, tingkat depresi pada mencit dapat diukur dengan mengamati perilaku mencit yang setara dengan gejala depresi manusia. Contoh perilaku tersebut antara lain sikap berdiam diri (imobilitas) ketika diberikan stressor yang setara dengan sikap pasrah pada manusia, penurunan higenitas atau perilaku grooming yang setara dengan sikap apatis, dan penurunan konsumsi makanan manis yang setara dengan anhedonia (Willner, 2005). Dalam penelitian ini, perubahan perilaku grooming dan sikap imobilitas akan diukur untuk mengetahui efek tempe terhadap gejala depresi yan diindukasi oleh metode UCMS.

Adapun tujuan dari penelitan ini adalah untuk mengetahui pengaruh tempe sebagai makanan paraprobiotik terhadap gejala depresi, khususnya perubahan perilaku grooming dan imobilitas pada mencit Balb/c. Penelitian ini memiliki beberapa batasan, yakni bahwa gejala depresi yang dimaksud merupakan gejala yang ditimbulkan metode UCMS dan bahwa pengukuran tingkat depresi dilakukan berdasarkan observasi langsung pada kondisi rambut mencit Balb/c, uji cipratan sukrosa, uji suspensi ekor, dan uji renang paksa pada mencit Balb/c.

\section{METODE PENELITIAN}

\section{Alat dan Bahan}

Alat yang digunakan dalam induksi dan tes depresi antara lain botol semprot, gelas beaker, kain hitam untuk merekayasa kondisi gelap-terang, kandang mencit, kandang transit, kanebo/kain pengering, lampu, meja, pengganjal untuk memiringkan kandang, pensil, scoring sheet, stopwatch, tail suspension apparatus, telepon genggam, timer, dan tripod.

Bahan yang digunakan adalah mencit, dan tempe. Mencit yang digunakan merupakan mencit Balb/c yang diperoleh dari PT Biofarma Bandung, berusia 3 bulan dengan berat awal 27-30 gram dan berjenis kelamin jantan. Tempe yang digunakan dibuat di Laboratorium Biologi Universitas Surya dengan menggunakan laru tempe yang berasal dari inokulasi kultur murni Rhizopus oligosporus milik Universitas Surya. Selain itu, bahan yang diperlukan adalah air, alkohol, selotip kertas, serbuk gergaji untuk alas kandang (bedding), sukrosa, dan tisu. 
Tabel 1. Jenis stressor yang digunakan untuk menginduksi depresi

\begin{tabular}{|c|c|c|c|}
\hline Stressor & & Waktu & Keterangan \\
\hline $\begin{array}{l}\text { Gangguan } \\
\text { sirkadian }\end{array}$ & siklus & $2 \times 12$ jam & Gelap atau terang konstan \\
\hline $\begin{array}{l}\text { Gangguan } \\
\text { sirkadian }\end{array}$ & siklus & $\begin{array}{l}\text { Per } 30 \text { menit selama } 8 \text { jam } \\
\text { atau } \\
\text { per } 2 \text { jam selama } 6 \text { jam }\end{array}$ & selang-seling gelap terang \\
\hline Bedding basah & & 1-6 jam & Penambahan $125 \mathrm{ml}$ air pada bedding \\
\hline Kandang basah & & 15-30 menit & $\begin{array}{l}\text { Penempatan dalam kandang tanpa bedding yang } \\
\text { diisi dengan air setinggi } 1 \mathrm{~cm} \text { (suhu air disarankan } \\
\text { sekitar } 30^{\circ} \mathrm{C} \text { ) }\end{array}$ \\
\hline Kandang kosong & & 1-6 jam & Penempatan dalam kandang tanpa bedding \\
\hline Kandang miring & & 1-4 jam & $\begin{array}{l}\text { Penempatan dalam kandang (tanpa bedding) } \\
\text { dengan posisi miring }\end{array}$ \\
\hline Suara predator & & $\begin{array}{l}10 \text { menit, } 30 \text { menit, atau } 3 \\
\text { jam }\end{array}$ & Penyiaran suara elang atau kucing \\
\hline Air panas/es & & 5 menit & Perendaman dalam air dingin atau air panas \\
\hline Pengekangan & & 3 jam & Dalam tabung berdiameter $4 \mathrm{~cm}$ sepanjang $12 \mathrm{~cm}$ \\
\hline
\end{tabular}

Tail suspension apparatus dibuat dengan dimensi Lebar 11,5 cm x Tinggi 60 $\mathrm{cm} \times$ Panjang $60 \mathrm{~cm}$ (dibagi 4 kamar dengan panjang masing-masing $15 \mathrm{~cm}$ ). Gelas beaker (Tinggi $25 \mathrm{~cm}$ x Diameter 17 $\mathrm{cm}$ ) berisi air setinggi $15 \mathrm{~cm}$ digunakan sebagai tabung renang paksa.

\section{Tahapan Penelitian}

Penelitian yang dilakukan berupa eksperimen laboratorium yang meliputi suplementasi makanan tikus dengan paraprobiotik tempe, proses induksi depresi, dan pengukuran tingkat depresi mencit. Eksperimen dilaksanakan pada November-Februari 2018, di Laboratorium Biologi Universitas Surya, Tangerang.

Paraprobiotik dalam penelitain ini diberikan melalui suplementasi pada pakan standar mencit dengan tempe atau laru tempe. Pakan bersuplementasi tersebut kemudian diberikan pada mencit seperti pakan standar (5 gr/hari/ekor). Tempe yang digunakan merupakan tempe yang telah direbus (10 menit) sehingga berupa paraprobiotik. Tempe lalu dikeringkan dalam oven $40^{\circ} \mathrm{C}$ semalaman kemudian dihaluskan dengan blender. Bubuk tempe kemudian dicampurkan dengan bubuk pakan mencit komersil, diadon menjadi satu, lalu dikeringkan kembali dengan oven. Sementara itu, laru tempe, yang sudah dalam bentuk bubuk, langsung dicampurkan dengan bubuk pakan standar dan diolah dengan cara yang sama seperti di atas. Metode pengolahan ini berdasarkan pada gabungan metode pengawetan tempe oleh Koswara (2009) dan Soka et al. (2014) dengan modifikasi. Dosis tempe yang diberikan sesuai dengan metode yang dilakukan oleh Soka et al. (2014), yakni 5: 100 terhadap jumlah total pakan standar, sedangkan rasio dosis laru tempe adalah 5:1000, disesuaikan dengan jumlah laru yang digunakan saat pembuatan tempe.

Induksi depresi pada mencit dilakukan sesuai Metode Unpredictable Chronic Mild Stress (UCMS) yang digunakan oleh Berger et al. (2010), Peng et al. (2012), Nollet et al. (2013) dan Frisbee et al. (2015) dengan modifikasi. Mencit diberikan serangkaian stressor ringan dengan urutan acak selama 5 minggu. Varian stressor yang digunakan dijelaskan pada Tabel 1.

Tingkat depresi diukur berdasarkan pengamatan perilaku mencit yang setara dengan indikator depresi pada manusia, yakni sikap berdiam diri (imobilitas) 
ketika diberikan stressor yang setara dengan sikap putus asa (Bergner et al., 2010) dan penurunan grooming yang setara dengan penurunan kepedulian diri/ self-care (Nollet et al., 2013). Pengukuran perilaku grooming dilakukan dengan pengamatan visual kondisi rambut dan uji cipratan sukrosa, sedangkan perilaku imobilitas diukur melalui uji renang paksa dan uji suspensi ekor pada mencit Balb/c.

\section{Pengamatan Kondisi Rambut}

Pengamatan kondisi rambut mencit dilakukan seminggu sekali sesuai metode Bergner et al. (2010) dan Nollet et al. (2013). Perbandingan visual diamati pada pada 8 bagian, yaitu kepala, leher, punggung, perut, ekor, kaki depan, kaki belakang, dan area genital. Area yang tampak normal (rambut mulus dan rapi) diberi skor 0, sedangkan yang tampak berantakan (rambut berdiri/ bernoda/ botak) diberi skor 1. Jika terdapat bagian rambut yang agak mengembang (kondisi agak berantakan), dapat diberikan skor 0,5. Total skor dari kedelapan area dirata-rata untuk dibandingkan antar kelompok perlakuan selama 3 minggu.

\section{Uji Cipratan Sukrosa}

Prosedur uji cipratan sukrosa (Sucrose Splash Test/SST) dilakukan mengikuti metode Frisbee et al. (2015). Dalam uji ini, mencit ditempatkan dalam kandang berlapis kain kemudian diciprati dengan larutan sukrosa kental (10\%) menggunakan botol semprot. Durasi mencit membersihkan diri (grooming), baik dengan menjilat atau menggaruk, dicatat selama 5 menit periode tes.

\section{Uji Suspensi Ekor}

Prosedur uji suspensi ekor (Tail Suspension Test/ TST), sesuai yang dijelaskan Bergner et al. (2010) dan (Can et al. (2012), dilakukan dengan menggantung mencit setinggi $\pm 35 \mathrm{~cm}$ dari permukaan alas dengan memasang tape pada ekor mencit ke kait/ rak selama durasi 6 menit. Waktu ketika mencit berhenti bergerak dan durasi imobilitas kemudian diukur dengan stopwatch sebagai variabel terukur. Kondisi imobilitas didefinisikan sebagai kondisi menggantung tidak bergerak, hanya menggerakan sedikit kaki depan, atau hanya berayun akibat momentum dari gerakan sebelumnya.

\section{Uji Renang Paksa}

Uji renang paksa (Forced Swim Test/FST) dilakukan sesuai metode yang dijelaskan oleh Castagné et al. (2009) dan Yankelevitch-Yahav et al. (2015) dengan modifikasi. Uji dilakukan dengan menempatkan mencit di dalam tabung berisi air dengan kedalaman tertentu sehingga kaki belakang mencit tidak menyentuh dasar tabung dan kaki depan tidak dapat berpegangan pada tepi tabung. Suhu air disesuaikan pada suhu ruang karena suhu air terlalu dingin dapat memicu perilaku renang lebih aktif. Durasi renang paksa adalah 6 menit dan waktu ketika mencit menunjukan tandatanda imobilitas dicatat.

\section{Rancangan Percobaan}

Evaluasi efek suplementasi paraprobiotik tempe terhadap gejala depresi menggunakan hewan coba mencit Balb/c yang dibagi dalam 4 kelompok, yakni kelompok netral (K-), kontrol depresi $(\mathrm{K}+)$, depresi+tempe $(\mathrm{T})$, dan depresi+laru tempe (LT). Berdasarkan metode resource equation (Charan \& Kantharia, 2013), masing-masing kelompok terdiri dari 5 ekor mencit.

\section{Metode Analisis}

Skor kondisi rambut pada 8 bagian tubuh dirata-rata sebagai acuan perilaku grooming kasar. Total durasi grooming selama SST setiap mencit digunakan sebagai acuan perilaku grooming terinduksi (Smolinsky et al., 2009).

Pengukuran waktu imobilitas pada FST dan TST dilakukan sesuai metode 
yang dijelaskan oleh Slattery and Cryan (2012). Perhitungan frekuensi masingmasing fase dilakukan dengan membagi jangka waktu 5 menit (300 detik) menjadi 60 bagian, masing-masing bagian selama 5 detik, lalu mengategorikan setiap bagian tersebut sebagai fase imobilitas atau fase bergerak tergantung pada gerakan yang mayoritas dilakukan mencit pada jangka 5 detik tersebut. Jika mencit hanya diam pada detik ke-3 hingga ke-5, maka bagian pertama dihitung 1 (satu) poin untuk fase mengambang. Sebaliknya, jika mencit berusaha kabur pada detik ke-4 hingga ke10, maka bagian kedua dihitung satu poin untuk fase berontak. Begitu seterusnya sepanjang 300 detik hingga didapat total 60 poin jika semua fase dijumlahkan.

Data skor kondisi rambut, durasi grooming (SST), dan waktu imobilitas (TST dan FST) dihitung nilai median, kuartil atas, dan kuartil bawah per kelompok. Data tersebut lalu diilustrasikan dalam bentuk box plot.

Oleh karena variansi (standar deviasi) yang besar dalam satu kelompok uji dan jumlah sampel yang terhitung kecil, data diuji dengan metode nonparametrik, yakni uji Mann-Whitney untuk membandingkan data antar kelompok dalam minggu yang sama dan uji Friedman untuk membandingkan data antar minggu. Jika diperlukan, digunakan uji Wilcoxson sign-rank untuk membandingkan data antara 2 minggu. Nilai p-value yang lebih kecil dari 0,05 menunjukkan nilai signifikan. Analisis dilakukan mengunakan piranti lunak SPSS ver.23.

\section{HASIL DAN PEMBAHASAN}

\section{Efek Terhadap Perilaku Grooming}

Perilaku grooming sebagai salah satu indikator gejala depresi pada mencit diukur dengan dua metode. Pengukuran perilaku grooming secara umum didasarkan pada penurunan kebersihan kondisi rambut setiap minggu, sedangkan secara khusus didasarkan pada penurunan durasi grooming saat diinduksi dengan SST.

\section{Skor Kondisi Rambut}

Kondisi rambut mencit dari ketiga kelompok yang diinduksi depresi memburuk (semakin kotor dan berantakan) seiring waktu. Terlihat pada Gambar 1, skor kondisi rambut kelompok $\mathrm{K}+\left(\mathrm{X}^{2}(3)=\right.$ 8.846, $p$-value $=0,013), \mathrm{T}\left(\mathrm{X}_{(3)}^{2}=8.793, p\right.$ value $=0,003)$, dan $\mathrm{LT}\left(\mathrm{X}_{(5)}^{2}=10.510, p\right.$ value $=0,028)$ mengalami peningkatan signifikan antara sebelum induksi depresi $\left(\mathrm{H}_{0}\right)$ dan minggu ke-3 induksi depresi. Sementara itu, kondisi rambut kelompok yang tidak diinduksi depresi (K-) tidak mengalami perubahan signifikan.

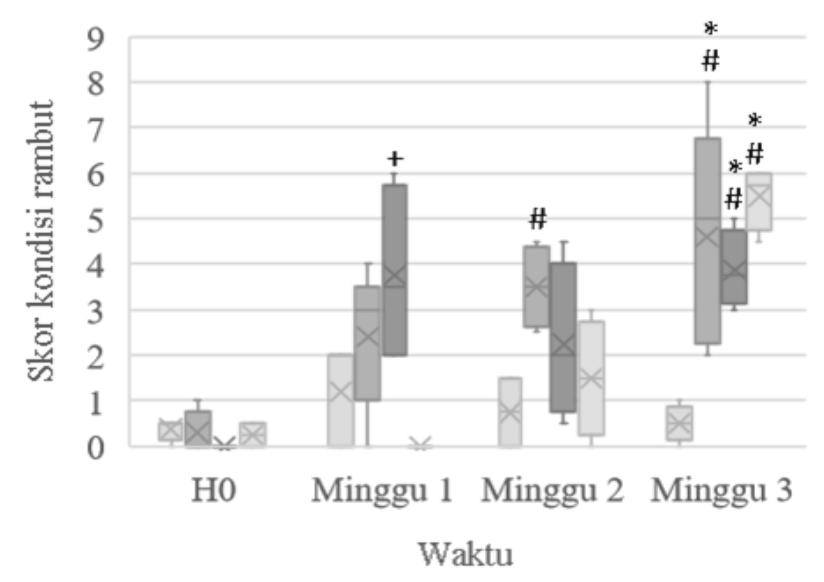

Gambar 1. Skor kondisi rambut mencit kelompok kontrol netral $(\square)$, kontrol depresi $(\square)$, perlakuan tempe ( $\square$ ) dan laru tempe ( $\square$ ) dan *: vs $\mathrm{H}_{0}$, p-value < 0,$05 ;+$ : vs LT, p-value < 0,05 ; \# : vs $\mathrm{K}-$, $\mathrm{p}$-value $<0,05$

Jika kondisi rambut mencit dibandingkan antar kelompok, perbedaan signifikan antara kelompok kontrol yang diinduksi depresi $(\mathrm{K}+)$ dan kelompok kontrol yang tidak diinduksi depresi (K-) telah teramati sejak minggu ke-2 ( $p$ value $=0,029)$, dengan median $[\mathrm{IQR}]$ untuk kelompok $\mathrm{K}$ - dan $\mathrm{K}+$ pada minggu ke-2 masing-masing adalah $3,5[2,875 ; 4,125]$ dan $0,75[0 ; 1,5]$. Sementara itu, perbedaan antara $\mathrm{K}$ - dengan kelompok yang diinduksi 
depresi disertai suplementasi paraprobiotik baru tampak pada minggu ke-3 (kelompok $\mathrm{T}: p$-value $=0,029$; kelompok LT: $p$-value $=$ 0,029), dengan median [IQR] untuk kelompok T, LT dan K- pada minggu ke-3 masing-masing adalah 3,75 [3,375;4,25], $5,75[5,25 ; 6]$, dan $0,5[0,375 ; 0,625]$.

Pada kelompok yang mendapat suplementasi paraprobiotik sendiri, kelompok yang diberi laru tempe menunjukkan kondisi rambut yang cenderung lebih baik. Pada minggu ke-1 induksi, skor kondisi rambut kelompok LT masih 0 [IQR 0,0], jauh di bawah kelompok $\mathrm{T}$ yang telah meningkat menjadi $3,5$ [IQR 2; 5,25] ( $p$-value $=0,029)$.

\section{Durasi Grooming Terinduksi}

Durasi grooming kelompok yang tidak diinduksi depresi (K-) menunjukkan peningkatan dari sebelum induksi hingga minggu terakhir induksi depresi $\left(\mathrm{X}^{2}{ }_{(4)}=9\right.$; p-value $=0,043) \quad($ Gambar 2). Durasi grooming kelompok K- bertambah dari 86 [IQR 71; 92] pada hari sebelum induksi menjadi 133 [IQR 121; 137] di minggu ke3 induksi. Hal ini sesuai dengan asumsi awal bahwa mencit yang tidak diinduksi depresi cenderung memperhatikan kebersihan dirinya dengan lebih baik. Pengamatan ini juga sejalan dengan data kondisi rambut kelompok $\mathrm{K}$ - yang menunjukkan kondisi lebih bersih/ rapi.

Kelompok $\mathrm{K}+$ dan $\mathrm{T}$ yang diinduksi depresi juga menunjukkan peningkatan dari awal induksi hingga akhir induksi, namun peningkatan tersebut tidak signifikan $\left(\mathrm{K}+: \mathrm{X}_{(4)}^{2}=7,525\right.$, p-value $=$ 0,$085 ; \mathrm{T}: \mathrm{X}_{(3)}^{2}=0,200$, p-value $\left.=1\right)$. Isingrini et al. (2010) dalam penelitiannya menemukan bahwa penerapan prosedur UCMS pada awalnya tidak menurunkan durasi grooming. Setelah prosedur UCMS diperpanjang, barulah terlihat bahwa durasi grooming tidak lagi mengalami peningkatan signifikan. Oleh karena itu, kemungkinan dalam penelitian ini pun perbedaan durasi grooming baru akan tampak jika prosedur UCMS diperpanjang.

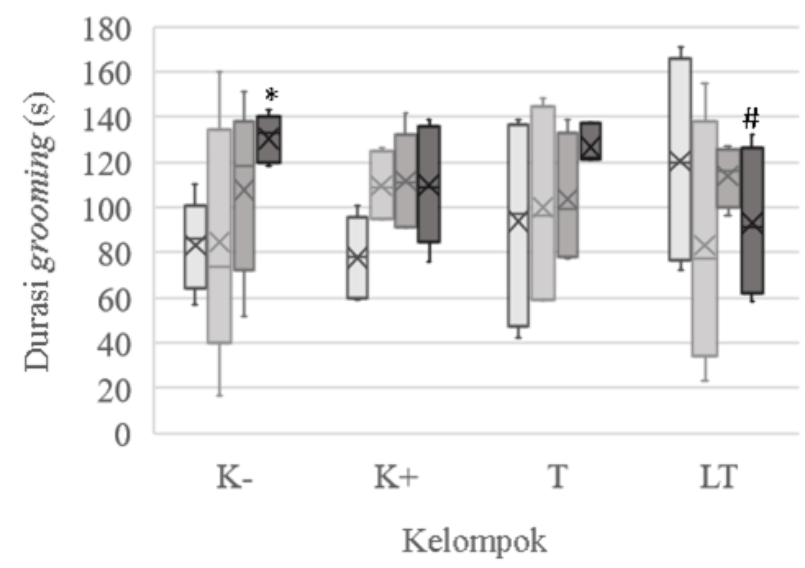

Gambar 2. Kurva durasi grooming SST pada waktu H0 ( $\square)$, minggu 1 ( $\square)$, minggu $2(\square)$, minggu $3(\square)$ dan *: vs $\mathrm{H}_{0}$ p-value < 0,05 , \#: vs $\mathrm{K}$-, $\mathrm{p}$-value $<0,05$

Hasil yang mencolok dari perubahan durasi grooming pada uji SST ini ditunjukkan oleh kelompok LT, yang justru menunjukkan trend penurunan durasi grooming setelah induksi depresi (Error! Reference source not found.). Bahkan, pada minggu ke-3, durasi grooming kelompok LT lebih rendah secara signifikan dengan kelompok K- ( $p$ value $=0,050)$. Hasil ini berlawanan dengan pengamatan kondisi rambut, yang menunjukkan kelompok LT justru memiliki rambut yang lebih rapi/bersih daripada kelompok $\mathrm{K}+$ dan $\mathrm{T}$. Hal tersebut kemungkinan berhubungan dengan efek tes berulang (repeated measure test) yang menyebabkan mencit lama kelamaan beradaptasi terhadap lingkungan tes. Efek ini teramati pada Open Fiels Test yang menguji tingkat kecemasan pada hewan pengerat dalam penelitian Sturman et al. (2018). Dalam penelitian tersebut, gejala kecemasan yang ditunjukkan berkurang pada tes-tes berikutnya diduga karena lingkungan tes tidak lagi terlalu aversif bagi mencit setelah berkali-kali mengekplorasi lingkungan tersebut. Efek ini pula yang diperkirakan terjadi pada tes SST kali ini, sebab kondisi lingkungan tes SST cukup mirip dengan tes OFT, yakni 
kotak bening kosong tempat mencit dapat bebas bereksplorasi sendirian.

Parameter yang diamati pada eksperimen OFT adalah perilaku rearing (berdiri di atas 2 kaki belakang) baik dengan sandaran maupun tidak. Frekuensi rearing yang tinggi menunjukkan tingginya sifat ekploratif dan rendahnya tingkat kecemasan mencit. Sementara itu, dalam SST, parameter yang diamati adalah jumlah aktivitas grooming yang dilakukan mencit sebagai indikasi kepedulian terhadap kebersihan diri (self-care). Kedua perilaku tersebut tidak dapat muncul bersamaan dan cenderung berlawanan satu sama lain karena mencit yang sibuk mengekplorasi lingkungan tidak akan memperhatikan kondisi kebersihan diri. Dapat dikatakan jika mencit lebih jarang melakukan rearing maka potensi mencit lebih sering melakukan grooming akan lebih besar. Dengan demikian, penurunan skor grooming mencit kelompok LT dalam SST sesuai dengan peningkatan skor rearing mencit dalam eksperiman OFT yang dilakukan Sturman et al. (2018).

\section{Efek Terhadap Waktu Imobilitas}

Waktu imobilitas mengacu pada durasi/frekuensi mencit berhenti berusaha meloloskan diri dari stressor yang diberikan. Semakin lama waktu imobilitas, semakin parah tingkat depresi mencit.

\section{Waktu Imobilitas Pada TST}

Hasil yang didapat dari uji ini agak berbeda dengan hasil uji lainnya. Tidak seperti uji lainnya, trend yang ditunjukkan kelompok K- justru peningkatan waktu imobilitas. Hal ini mengimplikasikan bahwa kelompok kontrol tersebut justru memiliki tingkat depresi lebih tinggi. Peningkatan durasi diam ini diduga disebabkan oleh penambahan running wheel (roda putar untuk bermain hamster). Penambahan tersebut nampaknya memperbaiki kondisi stress jika ditinjau dari segi kebersihan rambut dan berat badan, namun tampaknya dapat menganggu uji perilaku motorik. Richter et al. (2014) mengulas efek negatif pemberian roda putar pada hewan pengerat, salah satunya kemungkinan terjadinya deformasi pada ekor mencit tertentu yang dapat mempengaruhi fungsi lokomotif mencit sehingga dapat memberi hasil berbeda pada uji perilaku kecemasan.

Di sisi lain (Gambar 3), kelompok $\mathrm{K}+$ yang diinduksi depresi menunjukkan peningkatan durasi imobilitas dari sebelum induksi depresi (median $[\mathrm{IQR})=23$ [19;23]) ke minggu ke-2 induksi depresi (median $[\mathrm{IQR}]=30[28 ; 33,25] ; \mathrm{X}^{2}{ }_{(4)}=7,6$; $p$-value $=0,042)$. Sementara itu, kelompok yang mendapat suplementasi paraprobiotik ( $\mathrm{T}$ dan LT) terlihat memiliki frekuensi imobilitas yang lebih rendah dibandingkan kelompok $\mathrm{K}+$ yang diinduksi depresi tanpa suplementasi pararobiotik (Gambar 3). Pada minggu ke-2, ketika efek induksi depresi mulai tampak pada bertambahnya frekuensi imobilitas kelompok $\mathrm{K}+$ (30[IQR 28; 33,25]), frekuensi imobilitas kelompok yang diberi paraprobiotik tetap rendah $(\mathrm{T}=15,5[\mathrm{IQR} \quad 11,75 ; 20], p$ value $=0,029 ; \quad \mathrm{LT}=20,5 \quad[\mathrm{IQR} \quad 17,75$; 22,25], $p$-value $=0,029)$.

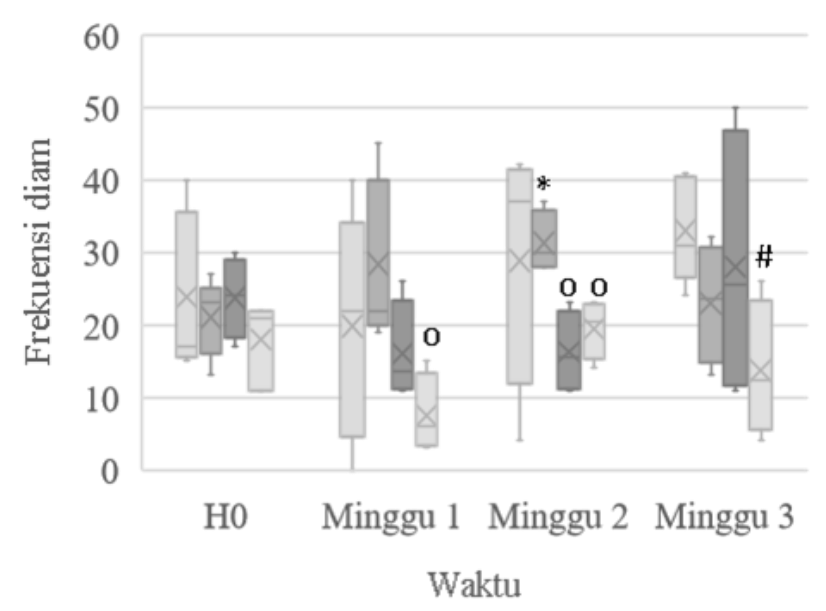

Gambar 3. Kurva waktu imobilitas TST kelompok kontrol netral $(\square)$, kontrol depresi $(\square)$ ), perlakuan tempe ( $\square$ ) dan laru tempe $(\square)$ dan $*$ : vs $\mathrm{H}_{0}$, p-value < 0,05 ; \# : vs K-, p-value < 0,05 ; o : vs $\mathrm{K}+$, p-value $<0,05$ 
Di antara kedua kelompok yang mendapat suplementasi paraprobiotik, kelompok LT menunjukkan performa yang lebih baik pada saat uji suspensi ekor. Terlihat pada Gambar 3, kelompok LT telah menunjukkan perbedaan signifikan dengan kelompok kontrol depresi $(\mathrm{K}+)$ sejak minggu ke-1 induksi depresi ( $\mathrm{LT}=6$ [IQR 3,75; 9,75]; $\mathrm{K}+=22$ [IQR 21; 35]; $p$ value $=0,016$ ), lebih awal dari kelompok $\mathrm{T}$ yang baru menunjukkan beda signifikan pada minggu ke-2. Ditambah lagi pada minggu ke-3, ketika terjadi anomali pada kelompok $\mathrm{K}+$ dan $\mathrm{K}$-, frekuensi imobilitas kelompok LT tetap paling rendah $(12,5$ [IQR 8,5; 17,75]) dan berbeda signifikan dengan kelompok $\mathrm{K}$ - $(p$-value $=0,032)$. Hal ini sejalan dengan hasil pengamatan kondisi rambut kelompok LT yang menunjukkan kondisi lebih baik dari kelompok kontrol yang tidak diinduksi depresi (K-).

\section{Waktu Imobilitas Pada FST}

Pada FST, frekuensi imobilitas kelompok K- yang tidak diinduksi depresi tidak menunjukkan hasil anomali seperti pada hasil TST. Terlihat pada Gambar 4, kelompok K- menunjukkan penurunan frekuensi imobilitas dari sebelum induksi depresi $\left(\mathrm{X}^{2}{ }_{(4)}=11,077\right.$; $p$-value $\left.=0,009\right)$.

Berkebalikan dengan hasil TST, kelompok kontrol depresi $(\mathrm{K}+)$ tidak menunjukkan peningkatan frekuensi imobilitas yang signifikan. Frekuensi imobilitas kelompok $\mathrm{K}+$ mengalami kenaikan dari 42 [IQR 21; 61] sebelum induksi menjadi 70,5 [IQR 69,75; 71,25] pada setelah empat minggu induksi depresi, namun perbedaan tersebut tidak mencapai nilai signifikan secara statistik $(p$-value $=0,367)$.

Hasil yang berlawanan pada uji FST dan TST memang dapat terjadi karena perbedaan mekanisme patofisiologis yang mendasari kedua tes (Cryan et al., 2005). Voiculescu et al. (2015) menemukan bahawa deprivasi melantonin menyebabkan perilaku depresif pada TST, sementara reaksi pada FST tetap normal. Mengingat dalam penelitian kali ini kelompok yang diinduksi depresi diberikan penerangan pada malam hari sebagai salah satu stressor, terdapat kemungkinan salah satu penginduksi perilaku depresif kelompok $\mathrm{K}+$ yang diamati pada TST adalah penurunan jumlah melantonin, yang tidak berpengaruh pada perilaku imobilitas di FST.

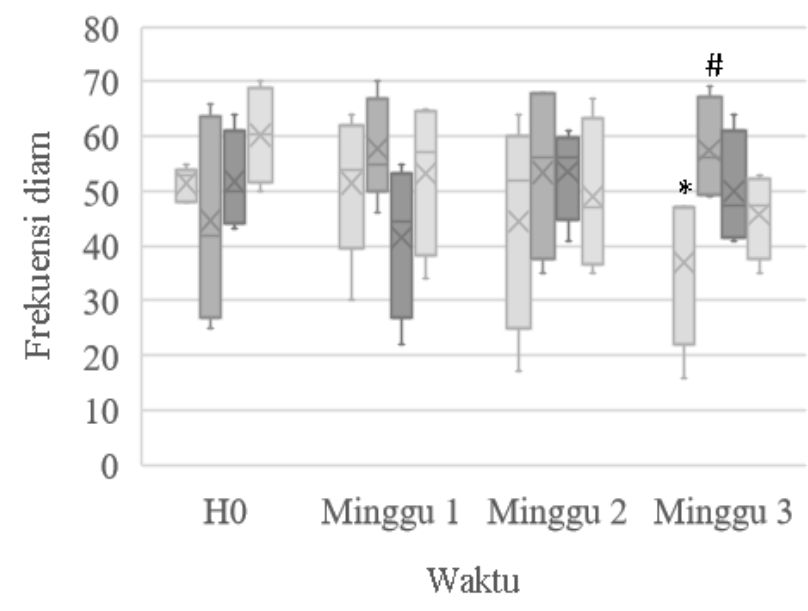

Gambar 4. Kurva waktu imobilisasi FST kelompok kontrol netral ( $\square)$, kontrol depresi ( $\square$ ), perlakuan tempe ( $\square$ ) dan laru tempe ( $\square$ ) dan *: vs $\mathrm{H}_{0,}$-value < 0,05 ; \#: vs $\mathrm{K}$-, $p$ value $<0,05$

Walaupun bila dibandingkan dengan frekuensi di awal induksi depresi, peningkatan frekuensi imobilitas kelompok $\mathrm{K}+$ tidak berbeda signifikan, terdapat perbedaan signifikan antara frekuensi imobilitas kelompok $\mathrm{K}+$ (56 [IQR 49,75; 63,75]) dan kelompok K- (47 [IQR 28;47]) di minggu ke-3 (p-value= 0,008). Kelompok yang tidak diinduksi (K-) semakin aktif bergerak setelah berkali-kali diceburkan dan menunjukkan adaptasi terhadap kondisi tes renang paksa, sedangkan kelompok mencit yang diinduksi depresi $(\mathrm{K}+)$ tetap lebih banyak berdiam diri. Perbedaan frekuensi imobilitas ini menunjukkan efek stressorstressor lain di luar gangguan siklus 
sirkadian mulai menginduksi timbulnya gejala depresi pada mencit $\mathrm{K}+$.

Sementara itu, hasil FST untuk kelompok yang diinduksi depresi disertai pemberian tempe (T) menunjukkan frekuensi imobilitas yang naik turun dan tidak jauh berbeda dari kelompok $\mathrm{K}+$, walupun cenderung lebih rendah (Gambar 4). Hasil ini berbeda dengan hasil TST yang menunjukkan penurunan signifikan frekuensi imobilitas kelompok $\mathrm{T}$ dibanding $\mathrm{K}+$ (Gambar 4). Perbedaan ini dapat disebabkan oleh kandungan triptofan yang merupakan prekursor serotonin pada tempe. Menurut Chatterjee et al. (2012), peningkatan aktivitas serotonin meningkatkan imobilitas pada FST, tetapi menimbulkan hiperaktivitas pada TST. Oleh sebab itu, tidak terlihatnya penurunan imobilitas FST pada kelompok $\mathrm{T}$ kemungkinan berhubungan dengan peningkatan kadar serotonin pada mencit Balb/c. Penelitian lanjutan yang mengukur kadar serotonin mencit dapat dilakukan untuk mengkonfirmasi hal tersebut.

\section{KESIMPULAN}

Pemberian tempe tidak memperbaiki kondisi rambut akhir ( $p$-value $=0,500)$ maupun mempengaruhi durasi grooming $(p$-value $=1)$ mencit Balb/c. Sementara pemberian laru tempe membuat kondisi rambut lebih baik daripada mencit Balb/c, yang tidak diinduksi depresi ( $p$-value $=$ 0,029), namun justru menurunkan durasi grooming hingga lebih rendah dari mencit yang tidak diinduksi depresi ( $p$-value= $0,05)$.

Pemberian paraprobiotik tempe dan laru tempe pada mencit Balb/c yang diinduksi depresi menurunkan waktu imobilitas pada TST dibandingkan dengan mencit Balb/c, kontrol depresi secara signifikan (T: $p$-value $=0,029 ; \mathrm{LT}: p$ value $=0$,029). Pada FST, hanya kelompok laru tempe yang menunjukkan penurunan gejala depresi namun dengan beda yang tidak signifikan $(p$-value $=0,239)$. Berdasarkan hasil pengamatan kondisi rambut dan TST, pemberian paraprobiotik dalam bentuk laru tempe memberi pengaruh yang lebih baik dalam menurunkan gejala depresi mencit Balb/c daripada paraprobiotik dalam bentuk tempe.

\section{DAFTAR PUSTAKA}

Astuti, M., Meliala, A., Dalais, F.S., and Wahlqvist, M.L. 2000. Tempe, a nutritious and healthy food from Indonesia. Asia Pacific Journal of Clinical Nutrition, 9 (4): 322-325.

Babu, P.D., Bhakyaraj, R., and Vidhyalakshmi, R. 2009. A low cost nutritious food "Tempeh"- A Review. World Journal of Dairy \& Food Sciences, 4 (1): 22-27.

Badan Penelitian dan Pengembangan Kesehatan. 2019. Hasil Riskesdas 2018. [Online]. Available at: http://www.depkes.go.id/resources/dow nload/info-terkini/hasil-riskesdas2018.pdf. [Diakses tanggal 10 Maret 2019].

Bergner, C.L., Smolinsky, A.N., Hart, P.C., Dufour, B.D., Egan, R.J., LaPorte, J.L., and Kalueff, A.V. 2010. Mouse Models for Studying Depression-Like States and Antidepressant Drugs. In: G. Proetzel \& M. V. Wiles, eds. Mouse Models for Drug Discovery. s.l.: Humana Press, pp. 267-282.

Bravo, J.A. Forsythe, P., Chew, M.V., Escaravage, E., and Savignac, H.M. 2011. Ingestion of Lactobacillus strain regulates emotional behavior and central GABA receptor expression in a mouse via the vagus nerve. PNAS, 08 (38): 16050-16055.

Can, A., Dao, D.T., Terrillion, C.E., Piantadosi, S.C., Bhat, S., and Gould, T.D. 2012. The tail suspension test. JoVe: Journal of Visualized Experiment, 59: e3769. 
Castagné, V., Moser, P., and Porsolt, R.D. 2009. Behavioral Assessment of Antidepressant Activity in Rodents. In: B. JJ, ed. Methods of Behavior Analysis in Neuroscience. 2nd ed. Boca Raton (FL): CRC Press/Taylor \& Francis.

Charan, J., and Kantharia, N.D. 2013. How to calculate sample size in animal studies?. Journal of Pharmacology \& Pharmacotherapeutics, 4 (4): 303-306.

Chatterjee, M., Jaiswal, M., and Palit, G. 2012. Comparative evaluation of forced swim test and tail suspension test as models of negative symptom of schizophrenia in rodents. ISRN Psychiatry, Volume 2012: 595141.

Clapp, M. Aurora, N., Herrera, L., Bhatia, M., Wilen, E., and Wakefield, S. 2017. Gut microbiota's effect on mental health: The gut-brain axis. Clinics and Practice, 7 (987): 131-136.

Cryan, J.F., Mombereau, C., and Vassout, A. 2005. The tail suspension test as a model for assessing antidepressant activity: Review of pharmacological and genetic studies in mice. Neuroscience and Biobehavioral Reviews, 29: 571625 .

Dash, S., Clarke, G., Berk, M., and Jacka, F.N. 2015. The gut microbiome and diet in psychiatry: Focus on depression. Current Opinion Psychiatry, 28 (1): 1-6.

DeRubeis, R.J., Siegle, G.J., and Hollon, S.D. 2008. Cognitive therapy vs. medications for depression: Treatment outcomes and neural mechanisms. Nature Review Neuroscience, 9 (10): 788-796.

Desbonnet, L., Garrett, L., Clarke, G., Kiely, B., Cryan, J.F., and Dinan, T.G. 2010. Effects of the probiotic Bifidobacterium infantis in the maternal separation model of depression. Neuroscience, 170: 1179-1188.
Frisbee, J.C., Brooks, S.D., Stanley, S.C., and d'Audiffret, A.C. 2015. An unpredictable chronic mild stress protocol for instigating depressive symptoms, behavioral changes and negative health outcomes in rodents. JoVe: Journal of Visualized Experiments, 106: e53109.

Hasler, G. 2010. Pathophysiology of depression: Do we have any solid evidence of interest to clinicians?. World Psychiatry, 9 (3), 155-161.

Isingrini, E., Camus, V., Guisquet, A.-M.L., Pingaud, M., Devers, S., and Belzung, C. 2010. Association between repeated unpredictable chronic mild stress (UCMS) procedures with a high fat diet: A model of fluoxetine resistance in mice. PLoS One, 5 (4): e10404.

Krishnan, V., and Nestler, E.J. 2008. The molecular neurobiology of depression. Nature Insight Review, 455: 894-902.

Kuligowski, M., Jasinska-Kuligowska, I., and Nowak, J. 2013. Evaluation of bean and soy tempeh influence on intestinal bacteria and estimation of antibacterial properties of bean tempeh. Polish Journal of Microbiology, 62 (2): 189194.

Nollet, M., Guisquet, A.-M.L., and Belzung, C. 2013. Models of depression: unpredictable chronic mild stress in mice. Current Protocols in Pharmacology, 5 (65): 1-17.

Nuraida, L. 2015. A review: Health promoting lactic acid bacteria in traditional Indonesian fermented foods. Food Science and Human Wellness, 4 (2): $47-$ 55 .

Peng, Y.-L. Liu, Y.-N., Liu, L., Wang, X., Jiang, C.-L., \& Wang, Y.-X. 2012. Inducible nitric oxide synthase is involved in the modulation of depressive behaviors induced by unpredictable chronic mild stress.. Journal of Neuroinflammation, 9 (75): $1-12$. 
Richter, S.H., Gass, P., and Fuss, J. 2014. Resting is rusting: A critical view on rodent wheel-running behavior. Neuroscientist, 20 (4): 313-325.

Selhub, E.M., Logan, A.C., and Bested, A.C. 2014. Fermented foods, microbiota, and mental health: ancient practice meets nutritional psychiatry. Journal of Physiology Anthropology, 33 (1): 2.

Slattery, D.A., and Cryan, J.F. 2012. Using the rat forced swim test to assess antidepressant-like activity in rodents. Nature Protocol, 7 (6): 1009-1014.

Smolinsky, A.N., Bergner, C.L., LaPorte, J.L. and Kalueff, A.V. 2009. Analysis of Grooming Behavior and Its Utility in Studying Animal Stress, Anxiety, and Depression. In: T. D. Gould, ed. Mood and Anxiety Related Phenotypes in Mice: $\quad$ Characterization Using Behavioral Tests. Humana Press, pp. 21-36, New York.

Soka, S., Suwanto, A., Sajuthi, D., and Rusmana, I. 2014. Impact of tempeh supplementation on gut microbiota composition in sprague-dawley rats. Research Journal of Microbiology, 9 (4): 189-198.

Soka, S., Suwanto, A., Sajuthi, D., and Rusmana, I. 2015. Impact of tempeh supplementation on mucosal immunoglobulin A in Sprague-Dawley rats. Food Science and Biotechnology, 24 (4), 1481-1486.

Sturman, O., Germain, P., and Bohacek, J. 2018. Exploratory rearing: a contextand stress-sensitive behavior recorded in the open-field test. Stress, 21 (5): 443452.
Voiculescu, S., Rosca, A., Zeca, V., Zagrean, L., and Zagrean, A. 2015. Impact of maternal melatonin suppression on forced swim and tail suspension behavioral despair tests in adult offspring. Journal of Medicine and Life, 8 (2): 202-206.

Willner, P. 2005. Chronic mild stress (CMS) revisited: Consistency and behaviouralneurobiological concordance in the effects of CMS. Neuropsychobiology, 52 (2): 90-110.

World Health Organization, 2015. Depression Factsheet.

[Online]

Available at: http://www.who.int/mediacentre/factshe ets/fs369/en/ [Diakses tanggal 11September 2015].

World Health Organization. 2017. Depression and other common mental disorders: global health estimates.. [Online] Available at: https://apps.who.int/iris/handle/10665/2 54610. [Diakses tanggal 10 Maret 2019].

Yankelevitch-Yahav, R., Franko, M., Huly, A. and Doron, R. 2015. The forced swim test as a model of depressive-like behavior. JoVe: Journal of Visualized Experiments, 97: e52587. 